\title{
Citizenship Information Research at the School of Information and Media
}

\author{
Rita Marcella and Graeme Baxter
}

\begin{abstract}
Discusses recent and current research into citizenship information needs at the School of Information and Media, The Robert Gordon University, Aberdeen. Reviews the most important results from two large-scale, nation-wide surveys (funded by the British Library Research and Innovation Centre) of the citizenship information needs of the UK public, highlighting those occasions where the response in Scotland differed significantly from national trends. Outlines a current project, funded by the Economic and Social Research Council, studying the impact of the use of information and communication technologies on the communication of parliamentary information in the UK, with particular attention being paid to the situation in the three new devolved legislatures - the Scottish Parliament, the National Assembly of Wales and the Northern Ireland Assembly. The paper summarises the aims and objectives of the current project and provides a preview of the methodologies to be used, including the development of a novel interactive, electronically assisted interview technique.
\end{abstract}

\section{Introduction}

This paper will discuss the School of Information and Media's recent and forthcoming research into citizenship information needs and provision in the United Kingdom, and will pay particular attention to this research as it relates to Scotland and the Scottish public. Citizenship information, as defined by the authors, is:

information produced by or about national and local government, government departments and public sector organisations which may be of value to the citizen either as part of everyday life or in the participation by the citizen in government and policy formulation.

Between 1997 and 1999, the School conducted a research project, funded by the British Library Research and Innovation Centre (BLRIC), which investigated the extent to which members of the UK public have expressed or unexpressed needs for citizenship information, and which explored their preferred methods of acquiring this information. More recently, the School has been awarded a grant by the Economic and Social Research Council (ESRC) to 
study the impact of the use of information and communication technologies (ICTs) on the communication of parliamentary information in the UK, with particular attention being paid to the situation in the three new devolved legislatures - the Scottish Parliament, the National Assembly of Wales and the Northern Ireland Assembly. The ESRC project commenced in November 2000 and is to last for 11 months.

This paper will briefly outline the methodology used in the BLRIC project and will review some of the more significant results of that research, highlighting those occasions where the results in Scotland differed significantly from national trends. It will also summarise the aims and objectives of the new ESRC project, and will provide a preview of the methodologies to be used during this research, including the development of a novel interactive, electronically assisted interview technique.

\section{BLRIC Project}

The main elements of the BLRIC project were two large-scale, nation-wide surveys of the citizenship information needs and information seeking behaviour of the British public. The first of these was a questionnaire-based survey of just under 1,300 individuals. This questionnaire was distributed in public libraries, Citizens Advice Bureaux (CABx) and other generalist information and advice agencies throughout the UK, and was designed to gather some preliminary data on the public's use of and need for citizenship information. The Scottish organisations participating in this stage of the project were the Aberdeenshire Library and Information Service, the Aberdeen Citizens Advice Bureau and the Gordon Rural Action and Information Network: of the total number of responses, 143 (i.e. $11.1 \%$ of the total sample) were completed by users/clients of these three organisations. The second survey was designed to gather more in-depth, qualitative and extended responses, and consisted of personal doorstep interviews with almost 900 citizens, with the interviewees being selected using the random walk sample method. These interviews were carried out by undergraduate and postgraduate librarianship and information studies students. Of the total, 75 (8.4\% of the sample) were conducted in Scotland, all of them within the city of Aberdeen. The interview schedule paid particular attention to national and local government issues and to 'survival information' (i.e. information to help people overcome the problems that occur in day-to-day life), and also sought to investigate the concept of the well-informed and active citizen.

In addition to these two surveys, the BLRIC project also consisted of a series of 27 case study visits to the organisations in which the questionnaires had been distributed, and a series of 
nine focus group discussions comprising representatives, from Aberdeen and the North East of Scotland, of the following sector or interest groups:

- information providers

- local, national and European government

- women

- disabled people

- ethnic minority groups
- the business community

- the education sector

- elderly people

- jobseekers

The full results of the British Library project have been widely reported in the professional literature (Marcella and Baxter, 1998, 1999a-c and 2000a-e), but some of the more notable findings are presented here.

\section{Citizenship information need}

Around $85 \%$ of respondents had sought some form of citizenship information in the past. The topics on which information was most frequently required were: education, leisure and recreation, employment, transport and travel, the law, health care and welfare benefits. When asked for what reasons they had required such information, $49 \%$ of respondents had sought it for educational reasons, while significant proportions had done so for work-related reasons (35\%), family/personal reasons (33\%) or simply out of a general interest (33\%) (see Figure 1). Only $8 \%$ had sought information for political decision-making, suggesting a degree of apathy and a low level of participation. In Scotland, while educational reasons were ranked highest, the proportion citing these (39\%) was significantly lower than that nationally. When the respondents were questioned about future information need similar patterns were predicted, although there was a significant predicted increase in the need for information about the European Union. 
Figure 1: Reasons for requiring information

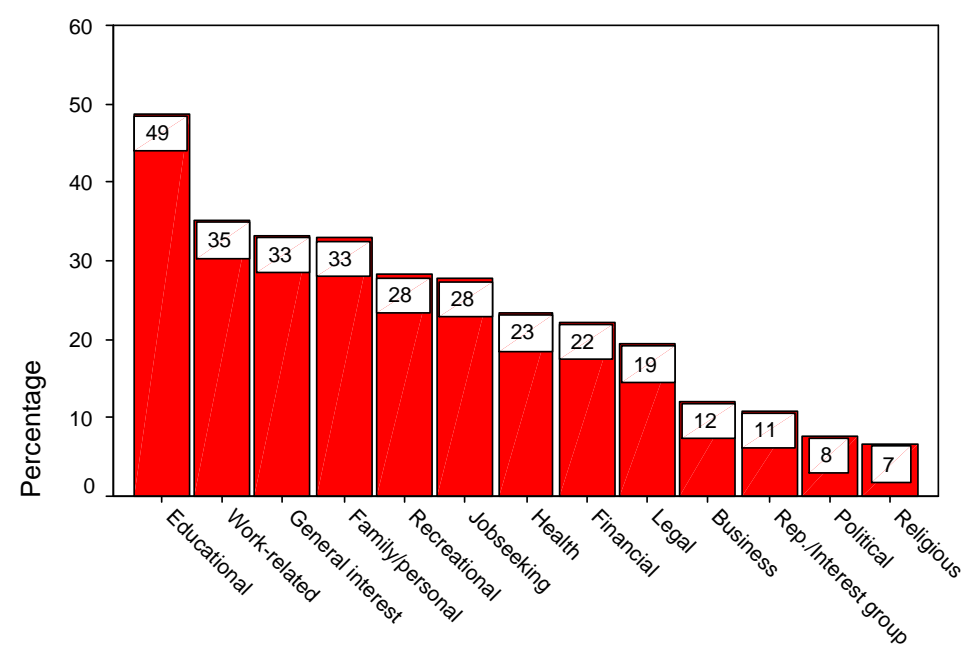

Reasons for requiring information

A quarter of respondents had encountered difficulties in accessing information, primarily on the law, education, welfare benefits, health and employment. Some dissatisfaction was expressed with the quality of legal and welfare benefits information obtained, and with information received from government departments and agencies.

Just over a quarter of respondents (26\%) cited an example of an occasion when not being able to obtain information had proven a disadvantage, although the proportion was considerably lower (17\%) amongst the Scottish respondents. Interestingly, those from higher social classes and those with the highest levels of educational qualification were more likely to be able to cite an example of disadvantage: contrarily this might suggest that these groups are more aware of disadvantage and its causes rather than they suffer greater disadvantage.

The situation in Northern Ireland dominated respondents' perception of the most significant current issue (i.e. in the summer of 1998). Otherwise a wide range of issues emerged, dominated by education, health care, Europe and the UK economy. Many of these topics were deemed by respondents to have a significant impact on their lives. There was evidence of very high levels of passive consumption of information from the media on subjects that respondents felt highly significant. There was greater reliance on television amongst lower classes and a greater tendency to use newspapers amongst the higher socio-economic groups. 
In a more detailed investigation of three current issues, the majority (59\%) felt well informed about the BSE crisis, but far smaller proportions felt well informed about European Monetary Union (25\%) and local government cutbacks (35\%). The majority felt that the Government should be doing more to inform citizens about the Single Currency $(80 \%)$ and about BSE (55\%), and that their local council should be providing more information about financial cutbacks $(72 \%)$.

While most respondents felt well or adequately informed about areas relating to citizenship, more than a quarter were poorly informed in legal rights, welfare benefits and local politics (see Figure 2). In Scotland, however, the proportions feeling poorly informed about these topics were considerably higher: welfare benefits (41\%), legal rights $(40 \%)$, local politics (37\%), equal rights (27\%), national politics (23\%).

\section{Figure 2: Percentage of respondents feeling poorly informed about areas relating to citizenship}

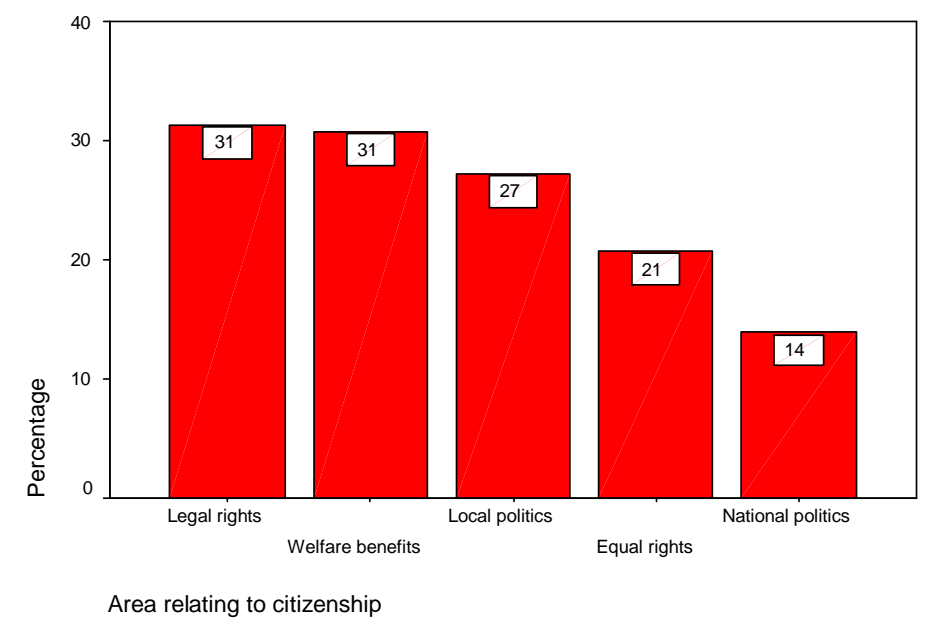

\section{Information seeking behaviour}

Over three quarters of respondents indicated that they would use public libraries to obtain information on at least an occasional basis, while between 50\% and 75\% would approach family and friends, government departments and agencies, post offices or CABx (see Figure 3). When compared with the entire sample, Scottish respondents were less willing to approach academic libraries (25\%). For most respondents it was the accessibility of the public library and the fact that they visited it regularly that made public libraries their preferred information source. Public libraries were also seen as reputable and having an appropriate atmosphere. 
Figure 3: Preferred sources of information

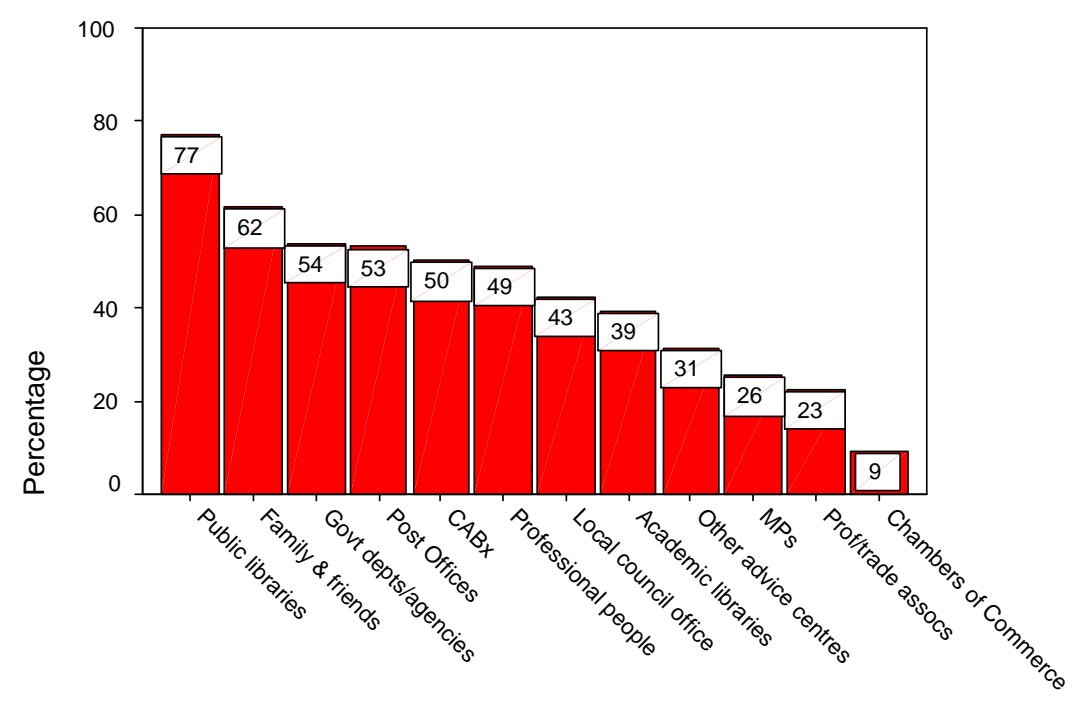

Preferred sources of information

Of the total sample, $73 \%$ were members of public libraries, although amongst the Scottish respondents the proportion was only 59\% (the Scottish figure being remarkably close to the national figure of 58\% cited recently by the Library and Information Commission (LIC, 1997)). The majority of respondents felt that public libraries were suitable places for obtaining information on their local council (82\%), consumer issues (68\%), welfare benefits (65\%), jobs and careers (61\%) and housing (54\%), although there was little evidence that many had approached public libraries for such information in the past. Curiously, the Scottish respondents appeared far less certain of the suitability of public libraries for obtaining consumer $(41 \%)$, benefits $(39 \%)$, careers $(33 \%)$ or housing (23\%) information.

Very significant numbers of respondents were unaware that public libraries hold official government publications (46\%), European Union information (61\%) and information on health care (45\%), legal rights (45\%) and educational opportunities (30\%). This lack of awareness was even more pronounced amongst respondents in Scotland.

When asked about their preferred methods of obtaining information, face to face communication was the most frequently cited method; although reading a book, browsing in a collection, reading a newspaper and using a telephone were also prominent. Only a small proportion expressed a preference for using a computer to seek information. However, as can be seen in Figure 4, when respondents were asked whether they would use computers if these 
were more widely available in public places, ICTs proved more popular. There was a clear emphasis on public libraries as an appropriate location for computerised information access, although other public places such as post offices, shopping centres and town halls would attract a significant proportion of the general public.

Figure 4: Predicted use of public access computers

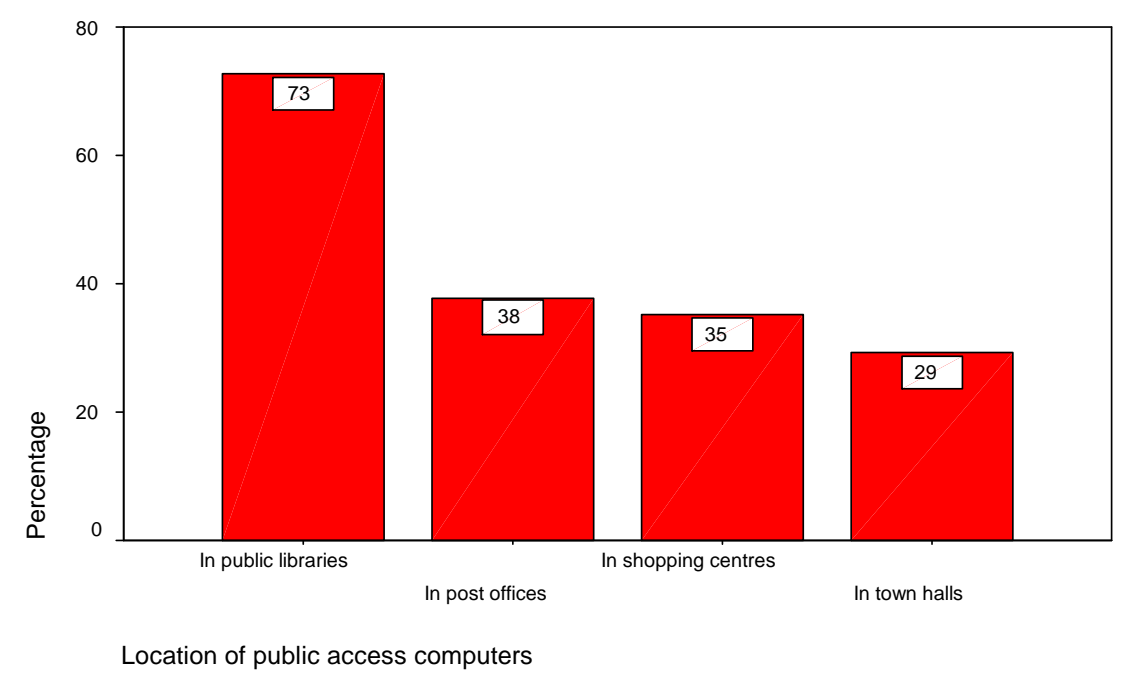

Potential use of computers for political participation was also high. The majority felt that they would be prepared to use computers to vote in elections (55\%), to convey opinions to government (54\%) and to obtain government information (60\%), although only a relatively small proportion (35\%) would use them to participate in political debate. Around a half of those who would use a computer to vote, provide feedback or debate were concerned about confidentiality.

\section{Perceived importance of information to citizens}

In the first survey, 94\% of respondents believed that access to accurate and unbiased information was very or quite important for exercising their rights as citizens. In Scotland, however, the proportion who felt that access was very important (69\%) was considerably lower than that nationally (79\%). This national figure was supported by the second survey, where the vast majority of respondents felt that freedom of information (92\%, see Figure 5) and access to accurate and unbiased information (also 92\%) were very or quite important. Again, however, the Scottish public appeared to be less convinced of the importance of information access: just $51 \%$ believed freedom of information to be very 
important, compared with the total sample figure of $67 \%$; while just $49 \%$ of the Scottish respondents felt that access to accurate and unbiased information was very important, compared with $72 \%$ nationally.

Figure 5: Perceived importance of freedom of information

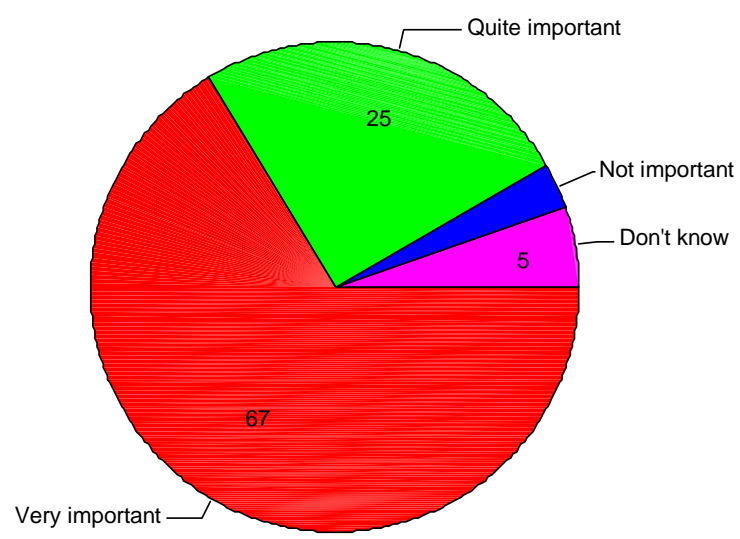

\section{What was learned about Scottish respondents?}

Overall, the results obtained from Scottish respondents painted a somewhat negative picture. When compared with the UK-wide sample, a smaller proportion of Scots had required information for educational purposes; while fewer cited an occasion of disadvantage through a lack of information. Scottish respondents were less likely to be members of a public library, and were less aware of the availability of citizenship information in public libraries. They were also less inclined to approach academic libraries for information. Respondents living in Scotland were also less convinced of the importance of freedom of information and of access to accurate and unbiased information.

\section{ESRC project}

The results of the BLRIC project highlighted several important issues relating to government information strategy. It is anticipated that a number of these, particularly those concerning the use of ICTs, will be explored further in the current ESRC project. The main aim of the ESRC project is to investigate the impact of new technology on the communication of 
parliamentary information from the perspectives of those in government, the information providers and the users of information. The more specific objectives are to:

- develop a model of parliamentary information provision to the public in the UK, in the context of a wider understanding of approaches globally;

- compare end-user approaches to parliamentary information in conventional and electronic form;

- explore, in particular, the actual benefits/drawbacks of technologically supported approaches for certain groups deemed to be in danger of exclusion; and

- develop and evaluate an interactive, electronic interview as a data collection tool employed as part of a pilot roadshow and to make recommendations for future application.

\section{Background and context of ESRC project}

The ESRC research is particularly timely in that it is taking place during the formative period of the three new devolved legislatures, each one of which is currently developing its own information strategies and services.

In 1998, the Consultative Steering Group (CSG) on the Scottish Parliament developed a draft Information Strategy, based on the Swedish Public Information Strategy, aimed at ensuring that 'the Parliament is as open, accessible and participative as possible'. It states that 'only well-informed citizens can maximise the opportunities which this presents for individuals and organisations to contribute to the democratic process'. (CSG, 1998a). To this end, the Scottish Parliament has established the Scottish Parliament Information Centre (SPICe), with an external information service - the Scottish Parliament Public Information Service - to meet the needs of the Scottish public. Between May and December 1999 the Public Information Service dealt with over 106,000 public contacts and queries (Nicol, 2000). SPICe has also launched a website containing the Official Report, research papers, draft legislation, news releases and a weekly newsletter What's Happening in the Scottish Parliament. A network of 76 Partner Libraries (all public libraries) has also been established to act as a focal point within local communities for information about the Parliament and its documentation and to provide, where possible, online access to the Parliament's website. Picton (1999) believes that the Scottish Parliament's 'open outlook' provides a unique 
opportunity for public access to official information, with far-reaching implications for other central and local government bodies.

The information service of the Welsh Assembly has also established a website providing public access to material such as the Record of Proceedings, committee proceedings, press notices, and legislative and consultative documents. In a scheme similar to the Scottish Parliament's Partner Library network, the Welsh Assembly has also established Information Link, a network of 40 public libraries providing access to all Assembly publications. Due to delays in the peace process, the information service of the Northern Ireland Assembly is not as advanced as those of its Scottish and Welsh counterparts, although the need for an 'open, transparent, accessible and accountable' Assembly with a 'high standard of information and communication systems' has been identified (Fee, 1999), and a website providing public access to the Official Report and other Assembly documentation has been established.

The current research is also timely in that it coincides with a number of major developments within the UK in terms of public access to parliamentary and other government information. The much delayed (and criticised) draft Freedom of Information Bill was published in May 1999 (Home Office, 1999). In July 1999, the Scottish Parliament introduced a non-statutory Code of Practice on Access to Scottish Executive Information (Scottish Executive, 1999a) but plans to replace this with a Freedom of Information regime for the devolved Scotland, issuing a consultation document on the subject in November 1999 (Scottish Executive, 1999b). The Welsh Assembly has also implemented a Code of Practice on Public Access to Information (1999); while the Executive Committee of the Northern Ireland Assembly is to discuss the introduction of separate Freedom of Information legislation for the Province (Trimble, 2000).

The UK Government has recently re-emphasised its commitment to what it terms 'information age government'. In April 2000, it published its strategic framework for egovernment (Cabinet Office, 2000), and the Prime Minister has set a new target that all dealings with government will be deliverable electronically by 2005 (Blair, 2000). The Scottish Executive was due to publish its draft e-government framework in October 2000 (Scottish Executive, 2000); while a parallel target - that all devolved public services in Scotland be available online by 2005 - has also been set (Dewar, 2000).

The establishment of the Scottish Parliament is seen as providing an excellent opportunity to develop our understanding of the impact of ICTs upon government/citizen interaction. The Advisory Committee on Telematics for the Scottish Parliament (1997) recommended the creation of an open parliament based upon state of the art ICTs, and suggested that there be 
online experimentation with citizens' panels, citizens' inquiries, deliberative polling groups, MSPs' surgeries, fora and town meetings. Coleman (1999) stated that 'if just some of these initiatives are followed through in the first few years of the new parliament, it will stand as a model of communicative democracy and will surely set an example for legislative assemblies across the world'. An Expert Panel on ICTs (CSG, 1998b) recommended that the Scottish Parliament should focus upon how ICTs may assist democratic participation, and the contribution that emerging technologies can make in enabling greater openness and accessibility. The Expert Panel suggested that the Scottish Parliament should 'aspire to be an example of best practice in parliamentary information systems', while aware of the danger of exclusion for marginalised, disillusioned and less educated groups. The Digital Scotland Task Force, a Scottish Executive initiative aimed at ensuring that Scotland obtains and retains maximum economic and social advantage from ICTs, produced a report, in May 2000, which stated that 'technology creates opportunities for more citizens to become more actively involved in public consultation and in the democratic process generally'. It recommended that the Scottish Executive provide such opportunities through the provision of online consultation (and online feedback on consultation), online opinion sampling, e-mail access to officials and elected members, and electronic voting. In its response, of September 2000, the Scottish Executive stated that 'concrete action is being taken to enhance its capability in online consultation', and indicated that it is also to consider implementing electronic voting pilots. Napier University's International Teledemocracy Centre, established in 1999 in partnership with BT Scotland, aims to develop innovative ICT-based applications that will strengthen public understanding and participation in government. Its current research includes the com.com/holyrood project, being carried out in conjunction with the Scottish Council for Voluntary Organisations, which aims to establish 200 Internet access points throughout Scotland to link Scotland's communities to the Scottish Parliament.

\section{ESRC project methodology}

The first stage of the ESRC project will consist of a series of interviews with representatives of the information services of the UK Parliament and the three new devolved legislatures. These interviews will gather data on the objectives and strategies of the services, and on the information access and dissemination activities developed by each one. By means of these interviews, the research will establish the current situation in each of the four legislatures and will highlight important initiatives and examples of best practice. 
As the second and main stage of the project, the research team is to develop an interactive, electronically assisted interview approach to data collection which will be taken out across the UK as part of a pilot 'roadshow'. This interview will constitute a new form of semistructured interview methodology, where members of the public will be encouraged to explore and respond to a number of predetermined parliamentary and other public information websites. Throughout these interviews, which will be conducted in a one-to-one situation, the interviewer will log responses to a set of structured questions as the examination proceeds. However, the interviews will also allow a free-form period of undirected information seeking on an appropriate topic and will utilise a combination of transaction log analysis and verbal protocol analysis (i.e. the interviewees will be prompted to 'think aloud' as their search progresses). In developing the interview, the project team are to consider previous studies of human-computer interaction in information seeking that have used such analytical methods.

The roadshow will consist of a minibus equipped with a laptop computer and remote Internet communications, together with print and visual aids in support. It will visit societies, organisations and institutions (e.g. public libraries, community centres, shopping centres, hospitals, sheltered accommodation, universities) that will facilitate access to a range of groups in the community, including both those thought to be in danger of social exclusion (e.g. elderly, unemployed and disabled people, women, ethnic minority groups and people living in rural areas) and those thought likely to be in a position already to make fuller use of ICTs (e.g. the academic, technical and business communities). The roadshow will last for a total of four weeks, with one week being spent in each of four UK towns or cities (one each in England, Scotland, Wales and Northern Ireland) and in their rural hinterlands. Ninety interviews are to be conducted in each location, giving a total of 360 interviews. While the roadshow events will be open to everyone, the interviewees will be selected using quota sampling, ensuring that all groups in the community are represented in the final sample.

The roadshow event is designed very much as a pilot, therefore a significant aspect of the ESRC project will be the post-execution evaluation of the methodologies used. It is anticipated, though, that the project will lead to the establishment, refinement and application of a valid and flexible data collection tool which could subsequently be used in a wide range of information and communication research contexts and with a wide variety of target groups. 


\section{References}

Advisory Committee on Telematics for the Scottish Parliament (1997), A parliament for the new Millennium, John Wheatley Centre, Edinburgh.

Blair, T. (2000), Government to speed up introduction of online services, press notice, 30 March, available online at http://www.number-10.gov.uk/news.asp?NewsId=744\&SectionId=33 (accessed September 2000)

Cabinet Office (2000), e-government: a strategic framework for public services in the information age, available online at http://www.citu.gov.uk/iagc/pdfs/Strategy.pdf (accessed September 2000)

Coleman, S. (1999), "Can the new media invigorate democracy?", The Political Quarterly, Vol. 70 No. 1, pp.16-22.

Consultative Steering Group on the Scottish Parliament (1998a), Information strategy for the Scottish Parliament, CSG Discussion Paper CSG(98)(77), available online at http://www.scottish-devolution.org.uk/csg/csg77.htm (accessed June 1999)

Consultative Steering Group on the Scottish Parliament (1998b), Information and communications technologies for the Scottish Parliament: current developments and future plans, CSG Discussion Paper CSG (98)(90), available online at http://www.scottishdevolution.org.uk/csg/csg90.htm (accessed March 1999)

Dewar, D. (2000), First Minister pledges faster progress to electronic future, press release, 31 March, available online at http://www.scotland.gov.uk/news/2000/03/se0928.asp (accessed September 2000)

Digital Scotland Task Force (2000), Digital Scotland Task Force report, available online at http://www.scotland.gov.uk/digitalscotland/report.htm (accessed September 2000)

Fee, J. (1999), Official Report (Hansard) of the Northern Ireland Assembly, 22 February, Line 300, available online at http://www.ni-assembly.gov.uk/hansard.htm (accessed September 2000)

Home Office (1999), Freedom of Information Bill, available online at http://www.homeoffice.gov.uk/foi/dfoibill.htm (accessed September 2000)

International Teledemocracy Centre, Home page, available online at http://www.teledemocracy.org/ (accessed September 2000)

Library and Information Commission (1997), New library: the people's network, LIC, London.

Marcella, R. and Baxter, G. (1998), "Citizenship information, electronic government", Information UK Outlooks, No. 31 (entire issue). 
Marcella, R. and Baxter, G. (1999a), "The citizenship information needs of the UK public: the quest for representativeness in methodological approach", in Wilson, T.D. and Allen, D.K. (Eds), Exploring the contexts of information behaviour: proceedings of the second international conference on research in information needs, seeking and use in different contexts, 13/15 August 1998, Sheffield, UK, Taylor Graham, London, pp.304-320.

Marcella, R. and Baxter, G. (1999b), "The information needs and the information seeking behaviour of a national sample of the population in the United Kingdom, with special reference to needs related to citizenship", Journal of Documentation, Vol. 55 No. 2, pp.159-183.

Marcella, R. and Baxter, G. (1999c), "A national survey of the citizenship information needs of the general public", Aslib Proceedings, Vol. 51 No. 4, pp.115-121.

Marcella, R. and Baxter, G. (2000a), "Citizenship information needs in the UK: results of a national survey of the general public by personal doorstep interview", Aslib Proceedings, 52(3), pp.115-123.

Marcella, R. and Baxter, G. (2000b), "Information need, information seeking behaviour and participation, with special reference to needs related to citizenship: results of a national survey", Journal of Documentation, Vol. 56 No. 2, pp.136-160.

Marcella, R. and Baxter, G. (2000c), "Citizenship information service provision in the UK: a study of 27 case agencies", Journal of Librarianship and Information Science, Vol. 32 No. 1, pp.9-25.

Marcella, R. and Baxter, G. (2000d), "The impact of social class and status on citizenship information need: the results of two national surveys of the population of the United Kingdom”, Journal of Information Science, Vol. 26 No. 4, pp.239-254.

Marcella, R. and Baxter, G. (2000e), "A random walk around Britain: a critical assessment of the random walk sample as a method of collecting data on the public's citizenship information needs", paper presented at the third international conference on information needs, seeking and use in different contexts, 16-18 August 2000, Gothenburg, Sweden, to be published in The New Review of Information Behaviour Research, 2000 or 2001.

National Assembly for Wales, Home page, available online at http://www.wales.gov.uk (accessed September 2000)

National Assembly for Wales (1999), Code of practice on public access to information, available online at http://www.wales.gov.uk/works/public_access_info/ codeofpracticecover_e.htm (accessed September 2000)

Northern Ireland Assembly, Home page, available online at http://www.ni-assembly.gov.uk/ (accessed September 2000) 
Nicol, K. (2000), "Public Information Centre statistics", What's happening in the Scottish Parliament, No. 26, 29 January 2000, available online at http://www.scottish.parliament.uk/whats_happening/whisp99-00/wh26-07.htm (accessed October 2000)

Picton, H. (1999), "Public access to information on the Scottish Parliament", Refer, Vol. 15 No. 2, pp.1-7, 11.

Scottish Executive (1999a), Code of practice on access to Scottish Executive information,. available online at http://www.scotland.gov.uk/library2/doc01/code.pdf (accessed September 2000)

Scottish Executive (1999b), An open Scotland: Freedom of Information, available online at http://www.scotland.gov.uk/library2/doc07/opsc-00.htm (accessed September 2000)

Scottish Executive (2000), Digital Scotland: the way forward, available online at http://www.scotland.gov.uk/digitalscotland/seresponse.asp (accessed September 2000)

Scottish Parliament, Home page, available online at http://www.scottish.parliament.uk (accessed September 2000)

Trimble, D. (2000), Official Report (Hansard) of the Northern Ireland Assembly, 7 February, Line 588, available online at http://www.ni-assembly.gov.uk/hansard.htm (accessed September 2000) 